Research Paper

\title{
Serum 1,25-dihydroxyvitamin D Better Reflects Renal Parameters Than 25-hydoxyvitamin D in Patients with Glomerular Diseases
}

Sungjin Chung1, 2, Minyoung Kim¹, Eun Sil Koh ${ }^{1}$, Hyeon Seok Hwang1, Yoon Kyung Chang1, Cheol Whee Park ${ }^{1}$, Suk Young Kim¹, Yoon Sik Chang 1 , Yu Ah Hong ${ }^{1 凶}$

1. Division of Nephrology, Department of Internal Medicine, College of Medicine, The Catholic University of Korea, Seoul, Republic of Korea;

2. Division of Nephrology and Hypertension, Department of Medicine, Vanderbilt University School of Medicine, Nashville, TN, USA.

$\square$ Corresponding author: Yu Ah Hong, MD, Address: Department of Internal Medicine, College of Medicine, The Catholic University of Korea, Daejeon St. Mary's Hospital, 64, Daeheung-ro, Jung-gu, Daejeon, 34943, Republic of Korea. Phone: +82-42-220-9329, Fax: +82-42-220-9473 E-mail address: amorfati@catholic.ac.kr

(C) Ivyspring International Publisher. This is an open access article distributed under the terms of the Creative Commons Attribution (CC BY-NC) license (https://creativecommons.org/licenses/by-nc/4.0/). See http://ivyspring.com/terms for full terms and conditions.

Received: 2017.04.07; Accepted: 2017.07.24; Published: 2017.09.04

Abstract

Background: Impaired vitamin D metabolism may contribute to the development and progression of chronic kidney disease. The purpose of this study was to determine associations of circulating vitamin $\mathrm{D}$ with the degree of proteinuria and estimated glomerular filtration rate (eGFR) in patients with biopsy-proven glomerular diseases.

Methods: Clinical and biochemical data including blood samples for 25 -hydroxyvitamin $D$ $(25(\mathrm{OH}) \mathrm{D})$ and 1,25 -dihydroxyvitamin $\mathrm{D}\left(1,25(\mathrm{OH})_{2} \mathrm{D}\right)$ levels were collected from patients at the time of kidney biopsy.

Results: Serum 25(OH)D levels were not different according to eGFR. However, renal function was significantly decreased with lower serum $1,25(\mathrm{OH})_{2} \mathrm{D}$ levels $(P<0.001)$. The proportions of nephrotic-range proteinuria and renal dysfunction (eGFR $\leq 60 \mathrm{~mL} / \mathrm{min} / 1.73 \mathrm{~m}^{2}$ ) progressively increased with declining $1,25(\mathrm{OH})_{2} \mathrm{D}$ but not $25(\mathrm{OH}) \mathrm{D}$. Multivariable linear regression analysis showed that $25(\mathrm{OH}) \mathrm{D}$ was significantly correlated with serum albumin and total cholesterol $(\beta=$ $0.224, P=0.006 ; \beta=-0.263, P=0.001$ ) and $1,25(\mathrm{OH})_{2} D$ was significantly correlated with eGFR, serum albumin and phosphorus $(\beta=0.202, P=0.005 ; \beta=0.304, P<0.001 ; \beta=-0.161, P=0.024)$. In adjusted multivariable linear regression, eGFR and $24 \mathrm{hr}$ proteinuria were independently correlated only with $1,25(\mathrm{OH})_{2} \mathrm{D}(\beta=0.154, P=0.018 ; \beta=-0.171, P=0.012)$, but not $25(\mathrm{OH}) \mathrm{D}$. The lower level of $1,25(\mathrm{OH})_{2} \mathrm{D}$ was associated with the frequent use of immunosuppressive agents $(P<0.001)$.

Conclusion: It is noteworthy in these results that circulating $1,25(\mathrm{OH})_{2} \mathrm{D}$ may be superior to $25(\mathrm{OH}) \mathrm{D}$ as a marker of severity of glomerular diseases.

Key words: Vitamin D; Biopsy; Glomerular disease; Proteinuria; Glomerular filtration rate.

\section{Introduction}

Vitamin D has been recognized for decades as a key player in the control of bone metabolism through regulating calcium and phosphate homeostasis [1]. Vitamin D is hydroxylated to 25-hydroxyvitamin D $(25(\mathrm{OH}) \mathrm{D})$ in the liver and converted into its active form, 1,25-dihydroxyvitamin $\mathrm{D}\left(1,25(\mathrm{OH})_{2} \mathrm{D}\right)$, by the enzyme 1a-hydroxylase [2]. The fact that 1a-hydroxylase is predominately, although not exclusively, found in renal tubular epithelial cells has suggested renal involvement in the process of vitamin D metabolism [3]. Indeed, the kidney plays a central role in vitamin $\mathrm{D}$ metabolism and in regulating its circulating levels, and thus any form or severity of renal disease may affect vitamin $\mathrm{D}$ metabolism 
through reduced 1a-hydroxylase activity, subsequent loss of renal capacity to generate $1,25(\mathrm{OH})_{2} \mathrm{D}$ and resultant decreases in serum $1,25(\mathrm{OH})_{2} \mathrm{D}$, tissue vitamin $\mathrm{D}$ receptor (VDR) content and their actions [3-5]. On the contrary, given that a number of experimental studies suggest that vitamin $\mathrm{D}$ axis has a renoprotective role [6-8], prosurvival vitamin D activity such as inhibiting the renin-angiotensin system (RAS), attenuating interstitial inflammation and reducing proteinuria help to maintain kidney health [3]. Thus, impaired vitamin D metabolism may contribute to the development and progression of kidney disease.

It is known that vitamin D-deficient individuals with normal renal function have low serum 25(OH)D levels in spite of normal glomerular filtration rates (GFRs) [3]. These low serum 25(OH)D levels result in marked reduction of the levels of $25(\mathrm{OH}) \mathrm{D}$ filtered and available for uptake by proximal kidney tubular cells, thereby compromising the activation of $25(\mathrm{OH}) \mathrm{D}$ to $1,25(\mathrm{OH})_{2} \mathrm{D}$ and the VDR induction of renal megalin for urinary protein reabsorption $[2,3]$. These findings may lay the foundation for pursuing serum vitamin $\mathrm{D}$ levels as potential markers of renal injury. Currently, both serum $25(\mathrm{OH}) \mathrm{D}$ and $1,25(\mathrm{OH})_{2} \mathrm{D}$ can be measured to evaluate vitamin $\mathrm{D}$ status. Because the 25-hydroxylation of vitamin $\mathrm{D}$ is mainly substrate dependent and $25(\mathrm{OH}) \mathrm{D}$ has a longer half-life than $1,25(\mathrm{OH})_{2} \mathrm{D}$, circulating levels of $25(\mathrm{OH}) \mathrm{D}$ are used to determine vitamin $\mathrm{D}$ status and the biological effects of vitamin D in clinical practice [9]. Some epidemiological studies have placed emphasis on monitoring serum $25(\mathrm{OH}) \mathrm{D}$ levels, because serum $25(\mathrm{OH}) \mathrm{D}$ has been thought to correlate well with clinical parameters including bone mineral density and immune system function [2]. However, some data have shown no definite association between serum $25(\mathrm{OH}) \mathrm{D}$ and kidney function after adjustment for confounders [10,11]. Rather, the level of $1,25(\mathrm{OH})_{2} \mathrm{D}$ has been reported to decline even in the early stage of chronic kidney disease (CKD), and this finding indicates that serum $1,25(\mathrm{OH})_{2} \mathrm{D}$ levels are closely associated with renal dysfunction [11].

The purpose of the present study was to investigate the relationships between circulating vitamin D levels and severity of glomerular diseases confirmed by kidney biopsy. Until now, few studies have been conducted to determine the usefulness of serum vitamin D levels as a renal injury indicator in patients with pathologically confirmed renal diseases. We compared levels of $25(\mathrm{OH}) \mathrm{D}$ and $1,25(\mathrm{OH})_{2} \mathrm{D}$ to determine which better reflected renal function parameters such as proteinuria and GFRs in patients with non-diabetic glomerular diseases.

\section{Materials and Methods}

\section{Study design}

A total of 199 adult patients underwent percutaneous native renal biopsies at The Catholic University of Korea Yeouido St. Mary's Hospital during the period from September 2011 to February 2015. The indications for kidney biopsy were isolated hematuria, proteinuria or renal dysfunction of unexplained cause. Percutaneous kidney biopsy was done by nephrologists under ultrasonographic guidance using an automated biopsy gun as previously described [12]. All subjects gave written informed consent before we obtained their kidney samples. Final histopathologic diagnosis on each sample was made comprehensively based on all the clinical data and pathologic findings. Cases showing diabetic nephropathy and tubular or interstitial diseases including acute tubular necrosis, tubulointerstitial nephritis and cast nephropathy were excluded in this study. Patients were divided into three groups according to their serum $25(\mathrm{OH}) \mathrm{D}$ and $1,25(\mathrm{OH})_{2} \mathrm{D}$ levels. This study was approved by the Institutional Review Board of The Catholic University of Korea Yeouido St. Mary's Hospital (SC16RISI0003) and performed in accordance with the principles of the Helsinki Declaration.

\section{Data collection}

Baseline demographic and clinical data at enrolment included age, sex, body mass index (BMI), presence of diabetes mellitus and hypertension, and medication history before and after kidney biopsy, including and RAS blockers and immunosuppressive agents such as steroids, cyclosporine and cyclophosphamide. In order to adjust for seasonal variation in vitamin D levels, we classified time points into four seasons as follows: spring (March to May); summer (June to August); autumn (September to November); and winter (December to February). We determined the serum levels of $25(\mathrm{OH}) \mathrm{D}, 1,25(\mathrm{OH})_{2} \mathrm{D}$, creatinine, albumin, sodium, potassium, corrected calcium, phosphorus, magnesium, intact parathyroid hormone (iPTH) and total cholesterol from blood samples. We calculated estimated GFR (eGFR) using the Modification of Diet in Renal Disease equations [13]. We corrected the measured serum calcium for albumin according to the following formula: serum corrected calcium $=$ calcium $+0.8 \times$ (4-albumin) (if albumin $<4.0 \mathrm{~g} / \mathrm{dL}$ ) [14]. For fractional excretion (FE) of sodium, calcium, uric acid, phosphorus and magnesium, we applied the following formula [15]: $\mathrm{FE} \mathrm{a}=[$ urine $\mathrm{a}(\mathrm{mEq} / \mathrm{L}) \times$ serum creatinine $(\mathrm{mg} / \mathrm{dL})$ / serum a $(\mathrm{mEq} / \mathrm{L}) \times$ urine creatinine $(\mathrm{mg} / \mathrm{dL})] \times 100$ 
(a: sodium, calcium, uric acid, phosphorus or magnesium).

\section{Statistical analysis}

Data for continuous variables with normal distributions are expressed as mean \pm standard deviation, and those without normal distributions are presented as the median and interquartile range. For multiple comparisons of the three groups, we used ANOVAs followed by post hoc correction for the continuous variables and used the $\chi^{2}$ test to compare the differences in categorical variables. Variables that were not normally distributed were log-transformed to achieve normality. We conducted univariable and stepwise multivariable linear regression analyses for independent variables adjusted for age, sex, and seasonal variation versus $25(\mathrm{OH}) \mathrm{D}$ and $1,25(\mathrm{OH})_{2} \mathrm{D}$ for dependent variables. We also conducted stepwise multiple linear regression analyses for independent variables versus $24 \mathrm{hr}$ proteinuria and eGFR for dependent variables and entered variables with $P<$ 0.1 on univariable analyses into the multivariable regression models. We considered $P<0.05$ to be statistically significant.

\section{Results}

\section{Baseline characteristics}

The present study included a total of 173 patients with non-diabetic glomerular diseases for the analysis. The pathologic kidney biopsy diagnoses were $\operatorname{Ig} \mathrm{A}$ nephropathy $(41.0 \%)$ followed by nonspecific mesangial proliferative

A

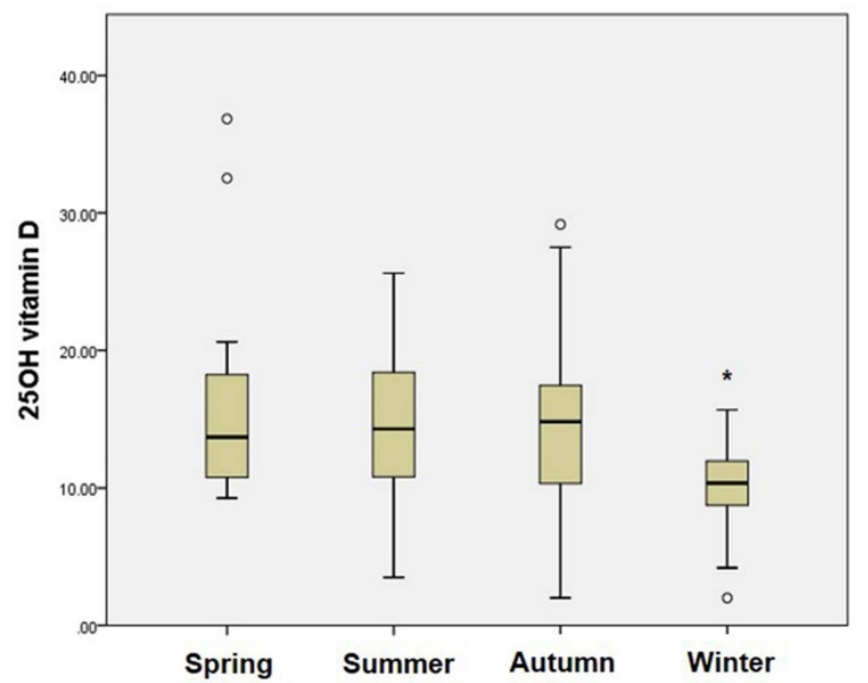

glomerulonephritis (23.7\%), focal segmental glomerulosclerosis $(13.8 \%)$, minimal change disease $(6.3 \%)$, membranous nephropathy $(4.0 \%)$, membranoproliferative glomerulonephritis (2.9\%), lupus nephritis $(1.7 \%)$, Henoch-Schönlein purpura nephritis $(1.7 \%)$, and others $(4.9 \%)$. The mean serum $25(\mathrm{OH}) \mathrm{D}$ and $1,25(\mathrm{OH})_{2} \mathrm{D}$ were $13.7 \pm 5.8 \mathrm{ng} / \mathrm{mL}$ (Range: 3.7-39.5 $\mathrm{ng} / \mathrm{mL}$ ) and $29.1 \pm 10.0 \mathrm{pg} / \mathrm{mL}$ (Range: 9.3-75.9 pg/mL), respectively. Serum $25(\mathrm{OH}) \mathrm{D}$ was significantly correlated with serum $1,25(\mathrm{OH})_{2} \mathrm{D}$ by partial correlation coefficient adjusted by age $(r=0.179 ; P=0.02)$. Fig. 1 shows the seasonal variations in $25(\mathrm{OH}) \mathrm{D}$ and $1,25(\mathrm{OH})_{2} \mathrm{D}$ in the study population. Levels of $25(\mathrm{OH}) \mathrm{D}$ were significantly lower in winter $(P<0.001)$, whereas $1,25(\mathrm{OH})_{2} \mathrm{D}$ did not differ by season.

The baseline characteristics of the study population segregated by baseline $25(\mathrm{OH}) \mathrm{D}$ and $1,25(\mathrm{OH})_{2} \mathrm{D}$ levels are shown in Table 1 . There were no significant differences among age, sex, BMI, the presence of diabetes mellitus and hypertension, serum potassium, serum phosphorus, corrected calcium, serum magnesium and $\mathrm{iPTH}$ levels in analyses with tertiles of both $25(\mathrm{OH}) \mathrm{D}$ and $1,25(\mathrm{OH})_{2} \mathrm{D}$. Individuals with higher $25(\mathrm{OH}) \mathrm{D}$ had on average higher serum albumin and sodium but lower total cholesterol and $24 \mathrm{hr}$ proteinuria than did those with lower 25(OH)D concentrations. On average, patients with higher $1,25(\mathrm{OH})_{2} \mathrm{D}$ had higher serum albumin and eGFR but lower total cholesterol and $24 \mathrm{hr}$ proteinuria.

B

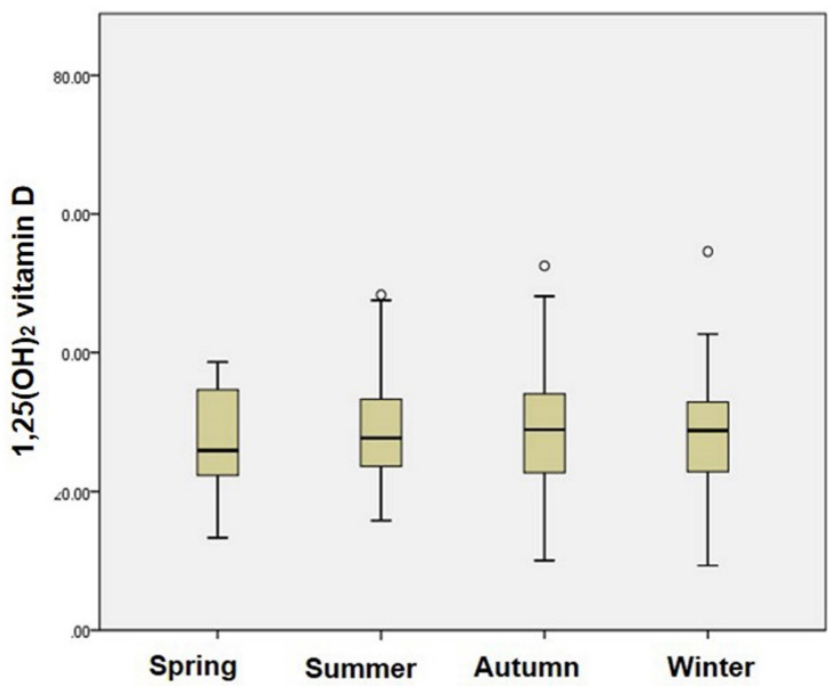

Figure 1. Seasonal variations in $25(\mathrm{OH}) \mathrm{D}$ and $1,25(\mathrm{OH})_{2} \mathrm{D}$ status in non-diabetic glomerular diseases. (A) Seasonal variation in $25(\mathrm{OH}) \mathrm{D}$. $* P<0.001$ vs. other seasons. (B) Seasonal variation in $1,25(\mathrm{OH}) 2 \mathrm{D}$. 
Table 1. Baseline characteristics according to $25(\mathrm{OH}) \mathrm{D}$ and $1,25(\mathrm{OH})_{2} \mathrm{D}$ tertiles in glomerular diseases

\begin{tabular}{|c|c|c|c|c|c|c|c|c|}
\hline & \multicolumn{4}{|l|}{$25(\mathrm{OH}) \mathrm{D}$} & \multicolumn{4}{|l|}{$1,25(\mathrm{OH})_{2} \mathrm{D}$} \\
\hline & $\begin{array}{l}1^{\text {st }} \text { Tertile } \\
(\mathrm{T} 1, \mathrm{n}=58)\end{array}$ & $\begin{array}{l}2^{\text {nd }} \text { Tertile } \\
(\mathrm{T} 2, \mathrm{n}=58)\end{array}$ & $\begin{array}{l}3^{\text {rd }} \text { Tertile } \\
(\mathrm{T} 3, \mathrm{n}=57)\end{array}$ & $P$ & $\begin{array}{l}1^{\text {st }} \text { Tertile } \\
(\mathrm{T} 1, \mathrm{n}=58)\end{array}$ & $\begin{array}{l}2^{\text {nd }} \text { Tertile } \\
(\mathrm{T} 2, \mathrm{n}=58)\end{array}$ & $\begin{array}{l}3^{\text {rd }} \text { Tertile } \\
(\mathrm{T} 3, \mathrm{n}=57)\end{array}$ & $P$ \\
\hline Age (yr) & $44 \pm 18$ & $45 \pm 16$ & $45 \pm 17$ & 0.983 & $45 \pm 18$ & $47 \pm 17$ & $42 \pm 15$ & 0.242 \\
\hline Sex (male, \%) & $28(48.3)$ & $29(50.0)$ & $37(64.9)$ & 0.145 & $30(51.7)$ & $32(55.2)$ & $32(56.1)$ & 0.882 \\
\hline $\mathrm{DM}(\%)$ & $8(13.8)$ & $4(6.9)$ & $6(10.5)$ & 0.477 & $6(10.3)$ & $9(15.5)$ & $3(5.3)$ & 0.198 \\
\hline HTN (\%) & $15(25.9)$ & $21(36.2)$ & $19(33.3)$ & 0.467 & $17(29.3)$ & $24(41.4)$ & $14(24.6)$ & 0.136 \\
\hline $\mathrm{BMI}\left(\mathrm{kg} / \mathrm{m}^{2}\right)$ & $23.8 \pm 3.9$ & $24.2 \pm 3.7$ & $23.5 \pm 3.8$ & 0.641 & $24.3 \pm 4.4$ & $24.3 \pm 3.4$ & $22.9 \pm 3.6$ & 0.083 \\
\hline Serum Creatinine $(\mathrm{mg} / \mathrm{dL})$ & $1.6 \pm 2.6$ & $1.1 \pm 0.4$ & $1.2 \pm 1.0$ & 0.244 & $1.7 \pm 2.3$ & $1.3 \pm 1.6$ & $0.9 \pm 0.2$ & 0.043 \\
\hline eGFR $\left(\mathrm{mL} / \mathrm{min} / 1.73 \mathrm{~m}^{2}\right)$ & $77.2 \pm 31.0$ & $80.3 \pm 26.0$ & $80.7 \pm 31.8$ & 0.786 & $69.0 \pm 34.3$ & $78.6 \pm 27.9$ & $90.8 \pm 21.3$ & $<0.001$ \\
\hline Serum Albumin (g/dL) & $3.7 \pm 1.1$ & $4.1 \pm 0.6$ & $4.1 \pm 0.6$ & 0.004 & $3.6 \pm 1.0$ & $4.1 \pm 0.6$ & $4.3 \pm 0.5$ & $<0.001$ \\
\hline Serum Sodium (mEq/L) & $140.0 \pm 3.4$ & $141.0 \pm 2.2$ & $141.3 \pm 1.8$ & 0.022 & $140.9 \pm 3.1$ & $140.9 \pm 2.8$ & $140.5 \pm 2.0$ & 0.759 \\
\hline Serum Potassium (mEq/L) & $4.1 \pm 0.5$ & $4.0 \pm 0.3$ & $4.1 \pm 0.3$ & 0.167 & $4.1 \pm 0.5$ & $4.1 \pm 0.4$ & $4.1 \pm 0.3$ & 0.971 \\
\hline Corrected Calcium (mg/dL) & $9.0 \pm 0.6$ & $9.0 \pm 0.4$ & $9.0 \pm 0.4$ & 0.797 & $9.0 \pm 0.5$ & $9.0 \pm 0.4$ & $9.0 \pm 0.4$ & 0.732 \\
\hline Serum Phosphorus (mg/dL) & $3.9 \pm 0.9$ & $3.7 \pm 0.6$ & $3.9 \pm 0.7$ & 0.329 & $4.1 \pm 0.8$ & $3.8 \pm 0.9$ & $3.7 \pm 0.6$ & 0.051 \\
\hline Serum Magnesium (mg/dL) & $2.2 \pm 0.2$ & $2.2 \pm 0.2$ & $2.2 \pm 0.2$ & 0.619 & $2.2 \pm 0.2$ & $2.2 \pm 0.2$ & $2.2 \pm 0.2$ & 0.727 \\
\hline Intact PTH $(\mathrm{pg} / \mathrm{mL})$ & $30.6 \pm 26.7$ & $26.8 \pm 14.5$ & $27.1 \pm 26.9$ & 0.634 & $33.9 \pm 34.0$ & $25.8 \pm 17.4$ & $25.0 \pm 12.3$ & 0.081 \\
\hline Total Cholesterol (mg/dL) & $212.8 \pm 84.1$ & $186.3 \pm 41.8$ & $183.2 \pm 38.4$ & 0.013 & $218.4 \pm 81.5$ & $183.4 \pm 43.8$ & $180.5 \pm 37.0$ & 0.001 \\
\hline 24hr Proteinuria (g/day) & $2.7 \pm 4.29$ & $9.84 \pm 1.69$ & $1.07 \pm 1.94$ & 0.002 & $2.99 \pm 4.22$ & $1.34 \pm 2.03$ & $0.50 \pm 0.76$ & $<0.001$ \\
\hline
\end{tabular}

Abbreviations: 25(OH)D: 25-hydroxyvitamin D; 1,25(OH) 2 D: 1,25-dihydroxyvitamin D; BMI: body mass index; BP: blood pressure; DM: diabetes mellitus; eGFR: estimated glomerular filtration rate; HTN: hypertension; PTH; parathyroid hormone

A

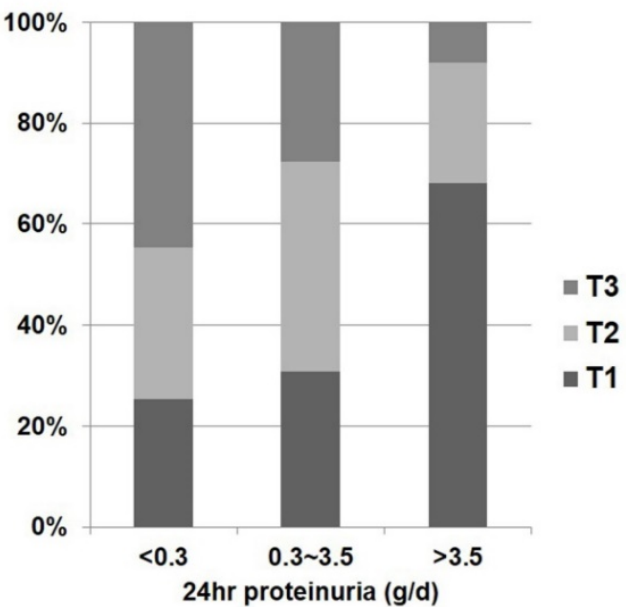

B

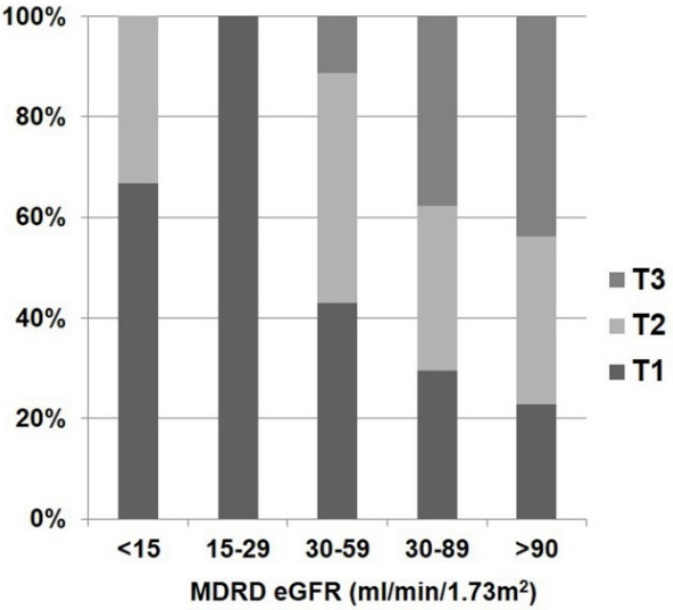

Figure 2. Distribution of $1,25(\mathrm{OH})_{2} \mathrm{D}$ status according to renal function and proteinuria in non-diabetic glomerular diseases. $(\mathrm{A}) 1,25(\mathrm{OH})_{2} \mathrm{D}$ and $24 \mathrm{hr}$ proteinuria. (B) $1,25(\mathrm{OH})_{2} \mathrm{D}$ and eGFR.

\section{Vitamin D and renal biochemical parameters}

In the whole patient group, eGFR was negatively correlated with log-transformed $24 \mathrm{hr}$ proteinuria when calculated using partial correlation coefficient adjusting for age $(r=-0.335 ; P<0.001)$. Correlations between vitamin $\mathrm{D}$ metabolites and clinical parameters in patients with glomerular diseases are shown in Fig. 2 and Table 2. Patients with nephrotic range proteinuria $(24 \mathrm{hr}$ proteinuria $>3.5 \mathrm{~g} /$ day) or moderate to severe renal dysfunction (eGFR $\leq 60$ $\mathrm{mL} / \mathrm{min} / 1.73 \mathrm{~m}^{2}$ ) were likely to have low $1,25(\mathrm{OH})_{2} \mathrm{D}$ $(P<0.001$ and $P<0.001$, respectively) (Fig. 2). However, the amount of proteinuria and severity of renal dysfunction were not associated with $25(\mathrm{OH}) \mathrm{D}$ ( $P=0.184$ and $P=0.898$, respectively) (Fig. 3).
Table 2 summarises the relationships between vitamin $\mathrm{D}$ metabolites and biochemical parameters on the basis of linear regression analysis. $\log 25(\mathrm{OH}) \mathrm{D}$ was positively correlated with serum albumin $(\beta=$ 0.374; $P<0.001)$ and serum magnesium $(\beta=0.159 ; P=$ $0.029)$ but negatively correlated with total cholesterol $(\beta=-0.392 ; P<0.001)$ and $\log 24 \mathrm{hr}$ proteinuria $(\beta=$ $-0.317 ; P<0.001)$. Meanwhile, $\log 1,25(\mathrm{OH})_{2} \mathrm{D}$ was positively correlated with eGFR $(\beta=0.292 ; P<0.001)$ and serum albumin $(\beta=0.378 ; P<0.001)$ but negatively correlated with serum creatinine $(\beta=$ -0.245; $P<0.001)$, serum phosphorus $(\beta=-0.245 ; P<$ $0.001)$, iPTH $(\beta=-0.223 ; P<0.001)$, total cholesterol $(\beta$ $=-0.257 ; P=0.001)$ and $\log 24 \mathrm{hr}$ proteinuria $(\beta=$ -0.361; $P<0.001)$. In stepwise multivariable linear regression, $\log 25(\mathrm{OH}) \mathrm{D}$ was independently 
correlated with serum albumin $(\beta=0.224 ; P=0.006)$ and total cholesterol $(\beta=-0.263 ; P=0.001)$, and log $1,25(\mathrm{OH})_{2} \mathrm{D}$ was independently correlated with eGFR $(\beta=0.202 ; P=0.005)$, serum albumin $(\beta=0.304 ; P<$ $0.001)$ and serum phosphorus $(\beta=-0.161 ; P=0.024)$.

Additionally, $\log 25(\mathrm{OH}) \mathrm{D}$ was positively correlated with $\log$ FE of phosphorus $(r=0.214 ; P=$ $0.006)$, whereas $\log 1,25(\mathrm{OH})_{2} \mathrm{D}$ was negatively correlated with log FE of magnesium $(r=-0.202 ; P=$ 0.010). Otherwise, there were no significant differences in $\mathrm{FE}$ of other ions according to either $25(\mathrm{OH}) \mathrm{D}$ or $1,25(\mathrm{OH})_{2} \mathrm{D}$ (data not shown).

\section{Vitamin $D$ and severity of glomerular diseases}

Table 3 shows the relationships between $25(\mathrm{OH}) \mathrm{D}$ or $1,25(\mathrm{OH})_{2} \mathrm{D}$ and eGFR or proteinuria in glomerular diseases. In stepwise multivariable linear regression, we detected significant associations between eGFR and $\log 1,25(\mathrm{OH})_{2} \mathrm{D}(\beta=0.237 ; P<$ 0.001) successively adjusted for age, sex, BMI, presence of diabetes mellitus and hypertension and
$24 \mathrm{hr}$ proteinuria. When further adjusted for serum total cholesterol, corrected calcium and phosphorus, eGFR was significantly associated with $\log$ $1,25(\mathrm{OH})_{2} \mathrm{D}(\beta=0.154 ; P=0.018)$. For proteinuria, both $\log 25(\mathrm{OH}) \mathrm{D}$ and $\log 1,25(\mathrm{OH})_{2} \mathrm{D}$ were significantly associated with $\log 24 \mathrm{hr}$ proteinuria $(\beta=$ $-0.221 ; P=0.002$ and $\beta=-0.227 ; P<0.001$, respectively) when we adjusted for age, sex, BMI, presence of diabetes mellitus and hypertension and eGFR. However, in the fully adjusted model, only log $1,25(\mathrm{OH})_{2} \mathrm{D}$ was significantly associated with $\log 24 \mathrm{hr}$ proteinuria $(\beta=-0.171 ; P=0.012)$.

Table 4 shows the distribution of patients on antiproteinuric therapy after kidney biopsy. Overall, there were no significant differences in use of RAS blockers by $25(\mathrm{OH}) \mathrm{D}$ and $1,25(\mathrm{OH})_{2} \mathrm{D}$ levels, although the patients with the highest $1,25(\mathrm{OH})_{2} \mathrm{D}$ but not $25(\mathrm{OH}) \mathrm{D}$ were likely to use less immunosuppressive agents $(P<0.001)$.

Table 2. Relationships between clinical parameters and $25(\mathrm{OH}) \mathrm{D}$ and $1,25(\mathrm{OH})_{2} \mathrm{D}$ in glomerular diseases

\begin{tabular}{|c|c|c|c|c|c|c|c|c|}
\hline & \multicolumn{4}{|c|}{$\log (25(\mathrm{OH}) \mathrm{D})$} & \multicolumn{4}{|c|}{$\log \left(1,25(\mathrm{OH})_{2} \mathrm{D}\right)$} \\
\hline & \multicolumn{2}{|c|}{ Univariable } & \multicolumn{2}{|c|}{ Multivariable } & \multicolumn{2}{|c|}{ Univariable } & \multicolumn{2}{|c|}{ Multivariable } \\
\hline & $\beta$ & $P$ & $\beta$ & $P$ & $\beta$ & $P$ & $\beta$ & $P$ \\
\hline BMI $\left(\mathrm{kg} / \mathrm{m}^{2}\right)$ & -0.063 & 0.391 & & & -0.170 & 0.027 & & \\
\hline Serum Creatinine (mg/dL) & -0.039 & 0.589 & & & -0.245 & 0.001 & & \\
\hline eGFR $\left(\mathrm{mL} / \mathrm{min} / 1.73 \mathrm{~m}^{2}\right)$ & 0.082 & 0.259 & & & 0.292 & $<0.001$ & 0.202 & 0.005 \\
\hline Serum Albumin (g/dL) & 0.374 & $<0.001$ & 0.224 & 0.006 & 0.378 & $<0.001$ & 0.304 & $<0.001$ \\
\hline Serum Sodium (mEq/L) & 0.118 & 0.105 & & & 0.012 & 0.882 & & \\
\hline Serum Potassium (mEq/L) & 0.008 & 0.112 & & & -0.031 & 0.699 & & \\
\hline Corrected Calcium (mg/dL) & -0.051 & 0.485 & & & 0.090 & 0.249 & & \\
\hline Serum Phosphorus (mg/dL) & -0.045 & 0.54 & & & -0.245 & 0.001 & -0.161 & 0.024 \\
\hline Serum Magnesium (mg/dL) & 0.159 & 0.029 & & & 0.017 & 0.826 & & \\
\hline Intact PTH $(\mathrm{pg} / \mathrm{mL})$ & -0.029 & 0.683 & & & -0.223 & 0.003 & & \\
\hline Total Cholesterol (mg/dL) & -0.392 & $<0.001$ & -0.263 & 0.001 & -0.257 & 0.001 & & \\
\hline 24hr Proteinuria (g/day) & -0.317 & $<0.001$ & & & -0.361 & $<0.001$ & & \\
\hline
\end{tabular}

Adjusted for age, sex, and seasonal variation. Abbreviations: 25(OH)D: 25-hydroxyvitamin D; 1,25(OH) 2 D: 1,25-dihydroxyvitamin D; BMI: body mass index; eGFR: estimated glomerular filtration rate; PTH: parathyroid hormone

A

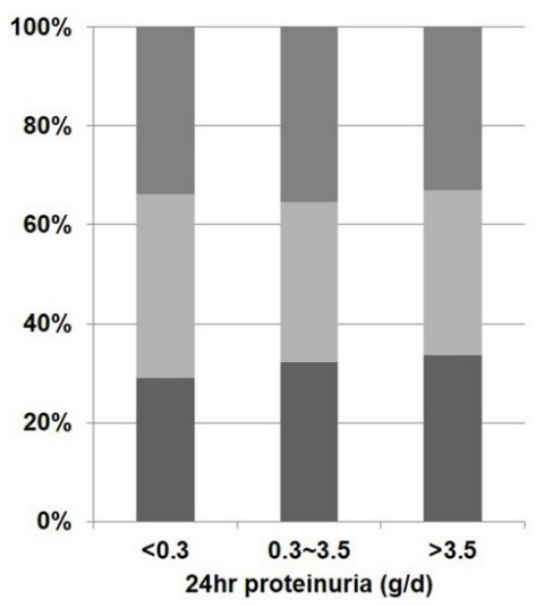

B

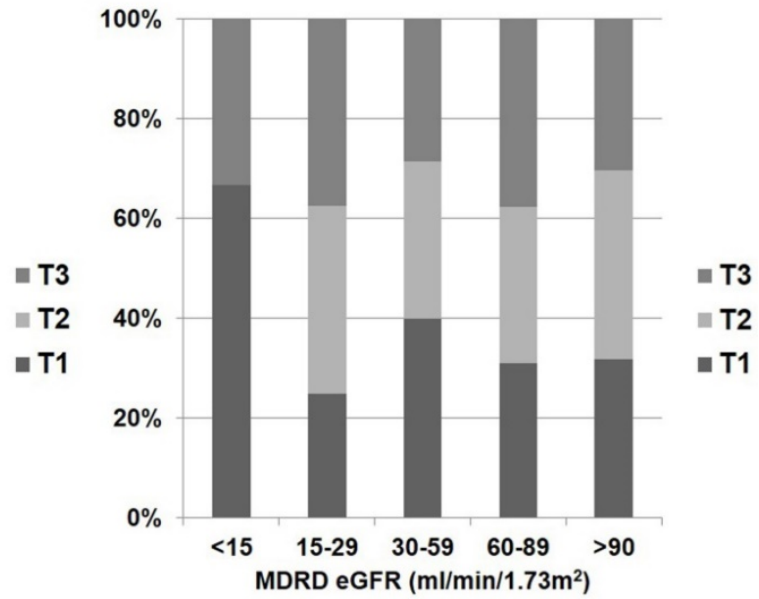

Figure 3. Distribution of $25(\mathrm{OH}) \mathrm{D}$ status according to renal function and proteinuria in non-diabetic glomerular diseases. $(\mathrm{A}) 25(\mathrm{OH}) \mathrm{D}$ and $24 \mathrm{hr}$ proteinuria. $(\mathrm{B})$ $25(\mathrm{OH}) \mathrm{D}$ and eGFR. 
Table 3. Multivariable linear regression between $25(\mathrm{OH}) \mathrm{D}$ or $1,25(\mathrm{OH})_{2} \mathrm{D}$ and estimated glomerular filtration rate or proteinuria

\begin{tabular}{lllll}
\hline & \multicolumn{2}{l}{$\log (\mathbf{2 5}(\mathrm{OH}) \mathrm{D})$} & \multicolumn{2}{l}{$\log \left(\mathbf{1}, \mathbf{2 5}(\mathrm{OH})_{2} \mathrm{D}\right)$} \\
\cline { 2 - 5 } & $\boldsymbol{\beta}$ & $\boldsymbol{P}$ & $\boldsymbol{\beta}$ & $\boldsymbol{P}$ \\
\hline eGFR & & & & \\
Unadjusted & 0.066 & 0.388 & 0.292 & $<0.001$ \\
Model 1 & 0.062 & 0.345 & 0.232 & $<0.001$ \\
Model 2 & 0.015 & 0.808 & 0.237 & $<0.001$ \\
Model 3 & 0.015 & 0.808 & 0.154 & 0.018 \\
24hr proteinuria & & & & \\
Unadjusted & -0.254 & 0.001 & -0.361 & $<0.001$ \\
Model 1 & -0.23 & 0.002 & -0.322 & $<0.001$ \\
Model 2 & -0.221 & 0.002 & -0.277 & $<0.001$ \\
Model 3 & -0.095 & 0.153 & -0.171 & 0.012 \\
\hline
\end{tabular}

Model 1 adjusted for age, sex and BMI, Model 2 adjusted for model 1+ diabetes mellitus, hypertension and eGFR (or $24 \mathrm{hr}$ proteinuria), Model 3 adjusted for model

$2+$ total cholesterol, calcium and phosphorus. Abbreviations: $25(\mathrm{OH}) \mathrm{D}$

25-hydroxyvitamin D; 1,25(OH $)_{2}$ D: 1,25-dihydroxyvitamin D; eGFR: estimated glomerular filtration rate

\section{Discussion}

In the current study, we demonstrated a significant negative relationship between serum baseline $1,25(\mathrm{OH})_{2} \mathrm{D}$ and proteinuria and a significant positive relationship between $1,25(\mathrm{OH})_{2} \mathrm{D}$ and eGFR in patients with biopsy-proven glomerular diseases. On the contrary, the baseline level of $25(\mathrm{OH}) \mathrm{D}$ was not associated with renal function and proteinuria. In addition, more patients with low serum $1,25(\mathrm{OH})_{2} \mathrm{D}$ received immunosuppressive agents than did those with high serum $1,25(\mathrm{OH})_{2} \mathrm{D}$. To our knowledge, the data shown herein are novel in their longitudinal link between serum $1,25(\mathrm{OH})_{2} \mathrm{D}$ concentrations and disease severity in patients with non-diabetic glomerular diseases confirmed by kidney biopsy.

Although diabetic nephropathy is currently the most common cause of end-stage renal disease [16], non-diabetic glomerulonephritis remains a major cause of morbidity and mortality from CKD in many regions of the world, particularly Asian countries [17]. As with any other causes of CKD, secondary hyperparathyroidism can begin relatively early in the course of glomerulonephritis and steadily progress as GFR declines. The pathogenic factors that could contribute to the development and maintenance of secondary hyperparathyroidism are multiple but principally involve the closely related consequences of phosphate retention and abnormalities in vitamin $\mathrm{D}$ metabolism [18]. Few studies have shown a relationship between renal function and abnormal calcium, abnormal phosphorus or vitamin $\mathrm{D}$ status in patients with non-diabetic glomerulonephritis. According to a Chinese study of 2,924 patients who had been newly diagnosed with primary glomerulonephritis, there was a significant decline in serum $25(\mathrm{OH}) \mathrm{D}$ in patients with CKD stage 5 [17]. However, the serum 25(OH)D was normal in patients with early-stage CKD. In our study, both $25(\mathrm{OH}) \mathrm{D}$ and $1,25(\mathrm{OH})_{2} \mathrm{D}$ levels were inversely proportional to the amount of urinary protein but only $1,25(\mathrm{OH})_{2} \mathrm{D}$ was proportional to eGFR. This finding suggests that serum $1,25(\mathrm{OH})_{2} \mathrm{D}$ is a more sensitive biomarker of renal function in glomerular diseases.

There are some grounds that serum $1,25(\mathrm{OH})_{2} \mathrm{D}$ reflects the severity of glomerular diseases. The pleiotropic effects of $1,25(\mathrm{OH})_{2} \mathrm{D}$ beyond controlling parathyroid function or mineral metabolism may extend to other areas in the course of renal disease [18]. One of these non-calcemic effects of vitamin D is suppression of RAS [19]. It has been well-known that vitamin $\mathrm{D}$ is a potent negative endocrine regulator of RAS and works predominantly as a suppressor of renin synthesis and angiotensin II accumulation in the kidney [18-20]. In cultured juxtaglomerular-like cells, the administration of active vitamin $\mathrm{D}$ reduces renin expression by $90 \%$ by blocking the cyclic adenosine monophosphate response element in the renin gene promoter [1]. Earlier clinical studies established a significant relationship between low circulating levels of $1,25(\mathrm{OH})_{2} \mathrm{D}$ and elevated serum renin [5]. Another explanation of vitamin D's effect on glomerular pathology is that vitamin $\mathrm{D}$ has intrarenal immunomodulating effects. In a previous study using 111 frozen kidney biopsy tissue samples, urinary monocyte chemoattractant protein (MCP)-1 and renal macrophage infiltration were each inversely correlated with serum $1,25(\mathrm{OH})_{2} \mathrm{D}$ levels [21]. This supports that $1,25(\mathrm{OH})_{2} \mathrm{D}$ inhibits the MCP-1 driven inflammatory process by blocking nuclear factor- $\mathrm{k} B$ activation [1,22]. Numerous studies have investigated the effects of $1,25(\mathrm{OH})_{2} \mathrm{D}$ on glomerular pathologies both in vivo and in vitro. The administration of $1,25(\mathrm{OH})_{2} \mathrm{D}$ diminished both proliferation of cultured mouse and human mesangial cells and secretion of transforming growth factor (TGF)- $\beta$ in human mesangial cells [23]. Furthermore, the administration of $1,25(\mathrm{OH})_{2} \mathrm{D}$ resulted in improved renal parameters such as proteinuria, mesangial proliferation and podocyte injury in a number of animal models of non-diabetic renal diseases including Heymann nephritis, cyclosporine A nephrotoxicity, subtotal nephrectomy, anti-Thy1.1 glomerulonephritis and puromycin aminonucleoside-induced nephrosis [1, $23,24]$. Based on data on the possible effects of vitamin $\mathrm{D}$ on glomerular health, one previous study evaluated the efficacy of vitamin $\mathrm{D}$ on proteinuria in patients with chronic glomerulonephritis. In a study of 10 patients with IgA nephropathy and persistent proteinuria despite use of RAS blockades, twice-weekly oral calcitriol therapy for 12 weeks demonstrated a modest antiproteinuric effect in these patients [25]. 
Table 4. Distribution of treatment after kidney biopsy according to the levels of vitamin $D$ metabolites in glomerular diseases

\begin{tabular}{|c|c|c|c|c|c|c|c|c|}
\hline & \multicolumn{4}{|l|}{$25(\mathrm{OH}) \mathrm{D}$} & \multicolumn{4}{|c|}{$1,25(\mathrm{OH})_{2} \mathrm{D}$} \\
\hline & T1 & $\mathrm{T} 2$ & T3 & $P$ & $\mathrm{~T} 1$ & $\mathrm{~T} 2$ & T3 & $P$ \\
\hline RAS blockers & & & & 0.35 & & & & 0.23 \\
\hline No & 11(19.0) & $8(13.8)$ & $4(7.0)$ & & 11(19.0) & $6(10.3)$ & $6(10.5)$ & \\
\hline Yes (Before biopsy) & $14(24.1)$ & $12(20.7)$ & $17(29.8)$ & & $16(27.6)$ & $17(29.3)$ & $10(17.5)$ & \\
\hline Yes (After biopsy) & $33(56.9)$ & $38(65.5)$ & $36(63.2)$ & & $31(53.4)$ & $35(60.3)$ & $41(71.9)$ & \\
\hline Immmunosuppressive agents & & & & 0.61 & & & & $<0.001$ \\
\hline No & $32(55.2)$ & $42(72.4)$ & $42(73.7)$ & & $31(53.4)$ & $34(58.6$ & $51(89.5)$ & \\
\hline Yes & $26(44.8)$ & $16(29.8)$ & $15(26.3)$ & & $27(46.6)$ & $24(41.4)$ & $6(10.5)$ & \\
\hline
\end{tabular}

Abbreviations: 25(OH)D: 25-hydroxyvitamin D; 1,25(OH $)_{2} \mathrm{D}$ : 1,25-dihydroxyvitamin D; RAS: renin-angiotensin system; T: tertile

There is also a possibility that serum $1,25(\mathrm{OH})_{2} \mathrm{D}$ in subjects with non-diabetic glomerulonephritis reflects early tubulointerstitial injury. Because the renal tubuleinterstitium is the primary site of hydroxylation of $25(\mathrm{OH}) \mathrm{D}$ to $1,25(\mathrm{OH})_{2} \mathrm{D}$, early dysfunction or loss of tubular and peritubular cells could impair the synthesis of $1,25(\mathrm{OH})_{2} \mathrm{D}$, causing the decreased local and systemic effects of the hormone. Furthermore, this could potentially result in further compromise to the functional and structural integrity of the renal parenchyma and contribute to the gradual decline of renal function [26]. Although much less was known about the effect of vitamin $\mathrm{D}$ on tubular interstitial fibrosis, it was found that $1,25(\mathrm{OH})_{2} \mathrm{D}$ suppressed the myofibroblast activation from interstitial fibroblasts, TGF- $\beta 1$-induced $\alpha$-smooth muscle actin expression, type I collagen and thrombospondin- 1 triggered by TGF- $\beta 1$ and $\beta$-catenin signalling [27]. Unlike serum calcium and phosphorus, serum magnesium is not regulated by a known hormone including vitamin $\mathrm{D}$, and most magnesium reabsorption occurs mainly in the thick ascending limb of loop of Henle [28]. Fractional excretion of magnesium increases as CKD evolves, maintaining normal serum magnesium levels until advanced CKD [29]. Considering the increased renal excretion of magnesium in subjects with low serum $1,25(\mathrm{OH})_{2} \mathrm{D}$ in our study, $1,25(\mathrm{OH})_{2} \mathrm{D}$ might be a marker for the diagnosis and monitoring of early tubular injury.

The major strength of our study is that we only included subjects who had percutaneous kidney biopsy and then were diagnosed with non-diabetic glomerular diseases, thereby setting an equal baseline for the effects of the underlying disease. An additional strength is that both $25(\mathrm{OH}) \mathrm{D}$ and $1,25(\mathrm{OH})_{2} \mathrm{D}$ with multiple renal functional parameters were simultaneously determined. Despite the presence of normal $25(\mathrm{OH}) \mathrm{D}$ levels, many patients with CKD tend to have low serum $1,25(\mathrm{OH})_{2} \mathrm{D}$, indicating the functional vitamin D deficiency in these patients [30]. Therefore, it may be more meaningful to measure serum $1,25(\mathrm{OH})_{2} \mathrm{D}$ with $25(\mathrm{OH}) \mathrm{D}$ at the same time in patients in the early stages of CKD. We should also note a number of limitations of the present study. First, the results are cross-sectional analyses and thus do not provide evidence of causation. Second, our sample size was rather small and all patients were from a single institution, so there may have been some selection bias. Third, the possible of residual confounding factors could not be excluded. Fourth, we did not measure other biomarkers associated with mineral metabolism, such as fibroblast growth factor 23 or Klotho. Finally, even though this study included only patients with non-diabetic glomerular diseases, a certain degree of heterogeneity might exist among different glomerulopathies.

\section{Conclusions}

In this study, we showed that circulating serum $1,25(\mathrm{OH})_{2} \mathrm{D}$ was superior to $25(\mathrm{OH}) \mathrm{D}$ as a marker of renal disease severity in patients with biopsy-proven glomerular disease. This finding may provide a thorough grounding in choosing vitamin D supplementation in these patients.

\section{Abbreviations}

1,25(OH $)_{2} \mathrm{D}: 1,25$-dihydroxyvitamin $\mathrm{D} ; 25(\mathrm{OH}) \mathrm{D}$ : 25-hydroxyvitamin D; BMI: body mass index; BP: blood pressure; CKD: chronic kidney disease; DM: diabetes mellitus; eGFR: estimated glomerular filtration rate; ESRD: end-stage renal disease; FE: fractional excretion; HTN: hypertension; iPTH: intact parathyroid hormone; MCP-1: monocyte chemoattractant protein-1; RAS: renin-angiotensin system; T: tertile; TGF- $\beta$ : transforming growth factor- $\beta$; VDR: vitamin D receptor

\section{Acknowledgements}

This research was supported by the Basic Science Research Program through the National Research Foundation (NRF) of Korea funded by the Ministry of Science, ICT \& Future Planning, Republic of Korea (NRF-2015R1C1A1A02037258). We thank Dr. Jong Hee Chung (Department of Statistics, The Graduate 
School of Ewha Womans University, Seoul, Republic of Korea) for her statistical advice.

\section{Authors' contributions}

S. Chung and Y. A. Hong designed the research. S. Chung, M. Kim, E. S. Koh, H. S. Hwang, Y. K. Chang, C. W. Park, S. Y. Kim, Y. S. Chang and Y. A. Hong collected and reviewed the data. S. Chung and Y. A. Hong performed the statistical analysis. S. Chung and Y. A. Hong wrote the paper. All authors read and approved the final manuscript.

\section{Competing Interests}

The authors have declared that no competing interest exists.

\section{References}

1. Doorenbos CR, van den Born J, Navis G, de Borst MH. Possible renoprotection by vitamin $\mathrm{D}$ in chronic renal disease: beyond mineral metabolism. Nat Rev Nephrol. 2009; 5: 691-700.

2. Jones G. Expanding role for vitamin D in chronic kidney disease: importance of blood 25-OH-D levels and extra-renal 1alpha-hydroxylase in the classical and nonclassical actions of 1alpha,25-dihydroxyvitamin $\mathrm{D}(3)$. Semin Dial. 2007; 20: 316-24

3. Dusso AS, Tokumoto $M$. Defective renal maintenance of the vitamin D endocrine system impairs vitamin D renoprotection: a downward spiral in kidney disease. Kidney Int. 2011; 79: 715-29.

4. Wang XX, Jiang T, Shen Y, Caldas Y, Miyazaki-Anzai S, Santamaria H, et al. Diabetic nephropathy is accelerated by farnesoid $X$ receptor deficiency and inhibited by farnesoid $X$ receptor activation in a type 1 diabetes model. Diabetes. 2010; 59: 2916-27.

5. Andress DL. Vitamin D in chronic kidney disease: a systemic role for selective vitamin D receptor activation. Kidney Int. 2006; 69: 33-43.

6. Ma J, Zhang B, Liu S, Xie S, Yang Y, Ma J, et al. 1,25-dihydroxyvitamin D(3) inhibits podocyte uPAR expression and reduces proteinuria. PLoS One. 2013; 8: e64912.

7. Zhang Z, Sun L, Wang Y, Ning G, Minto AW, Kong J, et al. Renoprotective role of the vitamin D receptor in diabetic nephropathy. Kidney Int. 2008; 73: 163-71.

8. Zou MS, Yu J, Nie GM, He WS, Luo LM, Xu HT. 1, 25-dihydroxyvitamin D3 decreases adriamycin-induced podocyte apoptosis and loss. Int J Med Sci. 2010; 7: 290-9.

9. Holick MF. Vitamin D deficiency. N Engl J Med. 2007; 357: 266-81.

10. LaClair RE, Hellman RN, Karp SL, Kraus M, Ofner S, Li Q, et al. Prevalence of calcidiol deficiency in CKD: a cross-sectional study across latitudes in the United States. Am J Kidney Dis. 2005; 45: 1026-33.

11. Levin A, Bakris GL, Molitch M, Smulders M, Tian J, Williams LA, et al. Prevalence of abnormal serum vitamin D, PTH, calcium, and phosphorus in patients with chronic kidney disease: results of the study to evaluate early kidney disease. Kidney Int. 2007; 71: 31-8.

12. Chung S, Koh ES, Kim SJ, Yoon HE, Park CW, Chang YS, et al. Safety and tissue yield for percutaneous native kidney biopsy according to practitioner and ultrasound technique. BMC Nephrol. 2014; 15: 96.

13. Levey AS, Bosch JP, Lewis JB, Greene T, Rogers N, Roth D. A more accurate method to estimate glomerular filtration rate from serum creatinine: a new prediction equation. Modification of Diet in Renal Disease Study Group. Ann Intern Med. 1999; 130: 461-70.

14. Payne RB, Little AJ, Williams RB, Milner JR. Interpretation of serum calcium in patients with abnormal serum proteins. Br Med J. 1973; 4: 643-6.

15. Musso CG, Juarez R, Vilas M, Navarro M, Rivera $H$, Jauregui $R$. Renal calcium, phosphorus, magnesium and uric acid handling: comparison between stage III chronic kidney disease patients and healthy oldest old. Int Urol Nephrol. 2012; 44: 1559-62.

16. Jin DC, Yun SR, Lee SW, Han SW, Kim W, Park J, et al. Lessons from 30 years' data of Korean end-stage renal disease registry, 1985-2015. Kidney Res Clin Pract. 2015; 34: 132-9.

17. Li Y, Zhang W, Ren H, Wang W, Shi H, Li X, et al. Evaluation of anemia and serum iPTH, calcium, and phosphorus in patients with primary glomerulonephritis. Contrib Nephrol. 2013; 181: 31-40.

18. Al-Badr W, Martin KJ. Vitamin D and kidney disease. Clin J Am Soc Nephrol. 2008; 3: 1555-60

19. Li YC, Kong J, Wei M, Chen ZF, Liu SQ, Cao LP. 1,25-Dihydroxyvitamin D(3) is a negative endocrine regulator of the renin-angiotensin system. J Clin Invest. 2002; 110: 229-38.

20. Zhang Z, Zhang Y, Ning G, Deb DK, Kong J, Li YC. Combination therapy with AT1 blocker and vitamin D analog markedly ameliorates diabetic nephropathy: blockade of compensatory renin increase. Proc Natl Acad Sci U S A. 2008; 105: 15896-901.

21. Zehnder D, Quinkler M, Eardley KS, Bland R, Lepenies J, Hughes SV, et al. Reduction of the vitamin $\mathrm{D}$ hormonal system in kidney disease is associated with increased renal inflammation. Kidney Int. 2008; 74: 1343-53.

22. Zhang Z, Yuan W, Sun L, Szeto FL, Wong KE, Li X, et al. 1,25-Dihydroxyvitamin D3 targeting of NF-kappaB suppresses high glucose-induced MCP-1 expression in mesangial cells. Kidney Int. 2007; 72: 193-201.

23. Panichi V, Migliori M, Taccola D, Consani C, Giovannini L. Effects of calcitriol on the immune system: new possibilities in the treatment of glomerulonephritis. Clin Exp Pharmacol Physiol. 2003; 30: 807-11.

24. Matsui I, Hamano T, Tomida K, Inoue K, Takabatake $Y$, Nagasawa $Y$, et al. Active vitamin $\mathrm{D}$ and its analogue, 22-oxacalcitriol, ameliorate puromycin aminonucleoside-induced nephrosis in rats. Nephrol Dial Transplant. 2009; 24 : 2354-61.

25. Szeto CC, Chow KM, Kwan BC, Chung KY, Leung CB, Li PK. Oral calcitriol for the treatment of persistent proteinuria in immunoglobulin A nephropathy: an uncontrolled trial. Am J Kidney Dis. 2008; 51: 724-31.

26. Singh DK, Winocour P, Summerhayes B, Viljoen A, Sivakumar G, Farrington $\mathrm{K}$. Are low erythropoietin and 1,25-dihydroxyvitamin D levels indicative of tubulo-interstitial dysfunction in diabetes without persistent microalbuminuria? Diabetes Res Clin Pract. 2009; 85: 258-64.

27. Tian J, Liu Y, Williams LA, de Zeeuw D. Potential role of active vitamin D in retarding the progression of chronic kidney disease. Nephrol Dial Transplant. 2007; 22: 321-8.

28. Blaine J, Chonchol M, Levi M. Renal control of calcium, phosphate, and magnesium homeostasis. Clin J Am Soc Nephrol. 2015; 10: 1257-72.

29. Felsenfeld AJ, Levine BS, Rodriguez M. Pathophysiology of Calcium, Phosphorus, and Magnesium Dysregulation in Chronic Kidney Disease. Semin Dial. 2015; 28: 564-77.

30. Agarwal R. Vitamin D, proteinuria, diabetic nephropathy, and progression of CKD. Clin J Am Soc Nephrol. 2009; 4: 1523-8. 